\title{
Simulasi Numerik untuk Pertumbuhan Retakan pada Bahan Heterogen: Studi Kasus pada Bitumen Aspal
}

\section{Numerical Simulation of Crack Growth in Heterogeneous Materials: Case Study on Asphalt}

\author{
Sayahdin Alfat ${ }^{1 *}$, Sudirman ${ }^{2}$ \\ 1,2)Jurusan Pendidikan Fisika, FKIP, Universitas Halu Oleo, Kendari, Sulawesi Tenggara. \\ Jl. Kampus Hijau Bumi Tridharma, Anduonohu, Sulawesi Tenggara 93232 Indonesia \\ *email: sayahdin.alfat@yahoo.com
}

\begin{abstract}
DOI;
ABSTRAK

10.30595/jrst.v4i1.5938

Penelitian ini bertujuan untuk menunjukkan perilaku pertumbuhan

Histori Artikel:

Diajukan:

$23 / 11 / 2019$

Direvisi:

$05 / 02 / 2020$

Diterima:

$15 / 03 / 2020$ retakan pada perkerasan aspal menggunakan model Takaishi-Kimura dan mengetahui tingkat kerusakan melalui energi elastisitas dan permukaan. Penelitian ini, telah menggunakan persamaan pertumbuhan retakan yang dikembangkan oleh Takaishi dan Kimura. Penelitian ini menggunakan Adaptive Finite Element Method dan Phase Field. Penelitian ini telah menggunakan 3 jenis desain yang berbeda sebagai berikut; (1) Retakan yang berasal dari bitumen aspal ke agregat; (2) Retakan yang berasal dari agregat ke bitumen aspal; dan (3) Retakan pada material heterogen. Asumsi yang digunakan yaitu; (1) Material bersifat heterogen; (2) Material bersifat linear elastis; (3) Material bersifat isotropic; (4) Pada kondisi awal tidak terjadi deformasi; (5) Panjang dan lebar retakan awal masing-masing sebesar 0.5 dan $5 \times 10^{-2}$; dan (6) body force diabaikan. Hasil penelitian telah menunjukkan bahwa ada pola retakan yang berbeda-beda untuk setiap desain. Disamping itu, lama retakan sempurna sangat bervariasi untuk setiap desain. Untuk energi elastisitas dan permukaan, semakin besar nilai energinya maka semakin lambat laju pertumbuhan retakan.
\end{abstract}

Kata Kunci: Adaptive Finite Element Method, Phase Field, Pertumbuhan Retakan, Material Heterogen.

\begin{abstract}
This study aims toshow behavior of crack growth in asphalt pavement by Takaishi-Kimura model and determine of damage level by elastic and surface energy. This research, has used the crack growth equation that developed by Takaishi and Kimura. This study used the Adaptive Finite Element Method and the Phase Field approach. This study has used 3 kinds of domains as follows; (1) Cracks originating from bitumen to aggregate; (2) Cracks originating from aggregate to bitumen; and (3) Cracks in heterogeneous material. The used assumptions were; (1) Material was heterogeneous; (2) Material was linear elastic; (3) The material was isotropic; (4) at the initial condition, there was no deformation; (5) Length dan width of initial crack have satisfied 0.5 and $5 \times 10^{-2}$, respectively; and (6) the body force was neglected. The results of the study have shown that there are different crack patterns for each design. Besides that, length of the perfect crack varies greatly for each design. For elasticity and surface energy, the greater the energy value, the slower the rate of cracks growth.
\end{abstract}

Keywords: Adaptive Finite Element Method, Phase Field, Crack Growth, Heterogeneous Material. 


\section{PENDAHULUAN}

Investigasi mengenai pertumbuhan retakan pada bahan homogen sudah sangat sering (Tilbrook et al., 2005). Namun pada kenyataannya, bahan alam didominasi oleh bahan dengan struktur yang heterogen. Salah satu bahan yang sering ditemukan yakni bitumen aspal pada kondisi tertentu. Aspal merupakan bahan pengikat yang menyatukan semua agregat dalam pembuatan jalan raya (Ritonga \& Irfandi, 2016). Akan tetapi, aspal sering kali mengalami deformasi permanen aktivitas tekanan yang berlebihan oleh lintas kendaraan di jalan raya dan perubahan temperatur, sehingga aspal jalan akan mengalami kerusakan/retakan (Mashuri \& Patunrangi, 2011).

Alfat dan Asfar menyatakan pertumbuhan retakan merupakan masalah yang sering terjadi dalam mekanika struktur, mekanika batuan dan geodinamika (Alfat \& Asfar, 2017). Memahami masalah ini sangat penting untuk mencegah akibat kerusakan yang ditimbulkan. Pertumbuhan retakan dan kerusakan pada bahan secara spesifik dapat diketahui melalui perubahan energi elastisitas dan energi permukaan serta pertambahan panjang retakan pada setiap pertambahan waktu.

Penelitian pertumbuhan retakan pada suatu bahan dapat dilakukan dengan metode ekperimen (Pfingsten \& Glien, 2006) dan metode numerik (Takaishi \& Kimura, 2010). Menurut Tanaka penelitian mengenai pertumbuhan retakan secara eksperimen atau uji laboratorium memiliki hasil yang baik, namun memiliki keterbatasan pada alat dan biaya yang sangat mahal (Tanaka, H.; Aoki, Y.; Yamamoto, 1997). Sedangkan penelitian dengan metode numerik menjadi alternatif karena secara ekonomi tidak banyak membutuhkan biaya, tidak membutuhkan waktu yang lama dan hasil yang diperoleh sangat akurat (Alfat et al., 2018). Ada beberapa metode numerik yang digunakan untuk mensimulasikan fenomena retakan yakni Finite Element Method (Font \& Periago, 2013; Takeshi \& Kimura, 2009), Discrete Element Method (Luding, 2008), Boundary Element Method (Antes, 2016) dan Metode Beda Hingga (Finite Different Method) (Causon \& Mingham, 2010). Namun menurut Alfat dan Asfar, Adaptive Finite Element Method sangat bagus karena hasil ketelitiannya sangat baik dan secara otomatis mendekteksi arah pertumbuhan retakan, serta mudah untuk didiskritisasi dan waktu komputasi lebih cepat (Alfat \& Asfar, 2017). Adaptive Finite Element Method merupakan salah satu metode numerik dan merupakan varians dari metode elemen hingga (Kimura et al., 2005).

Pendekatan phase field merupakan salah satu pendekatan matematik yang sangat powerfull untuk memvisualisasikan fenomena dalam fisika, seperti transfer massa, pertumbuhan kristal, sistem multiseluler, aliran fluida tak termampatkan dan pertumbuhan retakan. Di dalam memodelkan pertumbuhan retakan, pendekatan ini menggunakan 3 nilai yang berbeda yaitu; (1) jika $z=1$, maka kondisi bahan patah/retak, (2) jika bernilai $z=0$, maka bahan tidak rusak/retak, dan (3) jika $0<z<1$, maka bahan mengalami kerusakan (Takeshi \& Kimura, 2009). Berdasarkan kondisi tersebut, maka perlu dilakukan suatu investigasi secara mendalam mengenai pola atau perilaku pertumbuhan retakan pada 3 jenis bahan heterogen (bitumen aspal) yang masing-masing strukturnya berbeda, seperti Gambar 1. Lebih lanjut, trend energi elastisitas dan permukaan untuk masing-masing bahan akan divisualisasikan secara numerik. Hal ini diangap penting sebagai konsekuensi dari perbedaan karakteristik sturktur masing-masing bahan tersebut dan untuk melihat secara spesifik perubahan pertumbuhan retakan secara real time, waktu pertumbuhan retakan baru dan waktu kerusakan awal sebuah material. Secara keseluruhan penelitian ini menggunakan model pertumbuhan retakan yang dikembangkan oleh Takaishi dan Kimura. Pemilihan model ini karena tidak membatasi pada geometri tertentu atau dapat diterapkan pada geometri-geometri yang kompleks.

\section{METODE PENELITIAN}

\subsection{Persamaan Pertumbuhan Retakan}

Secara umum, pertumbuhan retakan dapat diselesaikan menggunakan persamaan diferensial parsial. Takaishi dan Kimura sudah memperkenalkan model pertumbuhan retakan yang didasarkan pada regulasi Ambrosio dan Tortorelli (Takeshi \& Kimura, 2009). Persamaan ini dapat diungkapkan dalam bentuk persamaan sistem reaction-diffusion yang memenuhi;

$$
\left\{\begin{array}{c}
\alpha_{1} \frac{\partial u}{\partial t}=\operatorname{div}\left((1-z)^{2} \sigma[u]\right)+f(x, t) \\
\alpha_{2} \frac{\partial z}{\partial t}=\left(\varepsilon \operatorname{div}(\gamma(x) \nabla z)-\frac{\gamma(x)}{\varepsilon} z+\cdots\right. \\
\sigma[u]: e[u](1-z))_{+}
\end{array}\right.
$$


dimana: $x$ adalah vektor posisi yang memenuhi $x=\left[x_{1}, x_{2}, x_{3}\right] \in \Omega, \quad u \quad$ adalah vektor displacement, $\sigma[u]$ adalah stress tensor, $e[u]$ adalah strain tensor, $\gamma$ adalah fracture toughness/energy release rate, $z$ adalah phase field parameter atau variabel kerusakan (Damage Variable) sedangkan $\alpha_{1}=0, \alpha_{2}$ dan $\varepsilon$ merupakan parameter komputasi.

Untuk menghindari suatu sistem terbalikan atau suatu sistem kembali ke keadaan semula maka pada persamaan (2) diatur dalam bentuk ( $)_{+}$pada sisi kanan persamaan ini, dimana $(a)_{+}=\max (a, 0)$ (Takeshi \& Kimura, 2009).

Riset ini berfokus pada pertumbuhan retakan di bawah Tearing Mode atau retakan model III. Dengan mengacu pada hal tersebut, maka persamaan (1) dan (2) dapat dituliskan menjadi;

$$
\left\{\begin{array}{l}
0=\mu \operatorname{div}\left((1-z)^{2} \nabla u\right) \\
\alpha_{2} \frac{\partial z}{\partial t}=\left(\varepsilon \operatorname{div}(\gamma \nabla z)-\frac{\gamma}{\varepsilon} z+\cdots\right. \\
\left.\mu|\nabla u|^{2}(1-z)\right)_{+}
\end{array}\right.
$$

dengan $u$ merupakan variabel displacement pada arah vertikal atau komponen $x_{3}$. Persamaan (3) dan (4) merupakan persamaan yang akan digunakan untuk menyelidiki pola atau perilaku pertumbuhan retakan pada bahan heterogen.

\subsection{Asumsi Penelitian}

Penelitian ini dirancang untuk melakukan simulasi pertumbuhan retakan pada bitumen aspal. Untuk memudahkan proses perhitungan komputasi, maka simulasi pertumbuhan retakan dalam penelitian menggunakan beberapa asumsi yakni sebagai berikut:

1. Dimensi material yakni $[-1,-1] \times[1,1]$

2. Material bersifat heterogen.

3. Material bersifat linear elastis.

4. Material bersifat isotropik, maka $\gamma(x)=\gamma$

5. Pada saat $\mathrm{t}=0$, tidak terjadi perubahan bentuk sehingga $u_{0}(x)=0$.

6. Pada saat $t=0$, terdapat retakan awal yang melintang secara horizontal sepanjang 0.5 dan berada pada $x_{2}=0$. Lebar retakan $(\delta)$ sebesar $5 \times 10^{-2}$. Secara matematis retakan awal memenuhi persamaan:

$$
z_{0}(x)=e^{-\left(x_{2} / 5 \times 10^{-2}\right)^{2}}\left(1+e^{\left(\frac{x_{1}-0,5}{5 \times 10^{-2}}\right)}\right)^{-1}
$$

\section{Body force diabaikan, $f(x, t)=0$}

Waktu simulasi yang digunakan $t_{\max }=15$ dengan interval waktu yang sangat kecil $(\tau=0.1)$.
Disamping itu, penelitian ini menggunakan beberapa parameter, yaitu $\varepsilon=10^{-3}, \alpha_{1}=0$, dan $\alpha_{2}=10^{-3}$. Sedangkan nilai Fracture Toughness bernilai $\gamma(x)=0.5$; karena ini material bersifat isotropik. Selain itu, penelitian ini juga menggunakan modulus Young $(E)$ dan Poisson ratio $(v)$ pada bitumen aspal bernilai $E_{1}=70$ dan $v_{1}=0.34$, serta pada agregat bernilai $E_{2}=90$ dan $v_{2}=0.14$. Konstanta Lame diperoleh dari persamaan berikut,

$$
\mu=\frac{E}{2(1+v)}
$$

dengan $E$ merupakan kombinasi antara $E_{1}$ dan $E_{2}$ serta $v$ juga merupakan kombinasi $v_{1}$ dan $v_{2}$.

\subsection{Syarat Batas}

Seperti yang sudah dijelaskan sebelumnya bahwa penelitian ini bertujuan untuk mengamati pola pertumbuhan retakan pada sebuah bahan heterogen di bawah Tearing Mode. Berdasarkan kondisi tersebut maka syarat batas yang digunakan memenuhi:

$$
\begin{cases}u=5 \times 10^{-2} t & \text { pada } \Gamma_{\mathrm{D}} \\ \frac{\partial z}{\partial n}=0 & \text { pada } \Gamma \backslash \Gamma_{\mathrm{N}}^{1} \\ z=0 & \text { pada } \Gamma_{\mathrm{N}}^{1} \\ \frac{\partial u}{\partial n}=0 & \text { pada } \Gamma_{\mathrm{N}}\end{cases}
$$

Variabel $\quad \Gamma_{\mathrm{D}} \quad$ dan $\quad \Gamma_{\mathrm{N}}$ masing-masing merepresentasikan syarat batas Dirichlet dan Neumann. Adapun variabel $\Gamma_{\mathrm{N}}^{1}$ merupakan bagian dari $\Gamma_{\mathrm{N}}$, secara matematis ditulisikan $\Gamma_{\mathrm{N}}$ : $=\Gamma_{\mathrm{N}}^{0} \cup \Gamma_{\mathrm{N}}^{1}$. Untuk $\Gamma$ adalah gabungan semua syarat batas atau dapat dituliskan sebagai $\Gamma:=$ $\Gamma_{\mathrm{D}} \cup \Gamma_{\mathrm{N}}$. Ilustrasi mengenai variabel syarat batas dapat dilihat melalui Gambar 1.

\subsection{Desain dan Algoritma Penelitian}

Penelitian ini menggunakan material heterogen, dimana pada material tersebut terdapat 2 jenis material yang berbeda, yakni material lunak atau bitumen aspal $\left(\Omega_{1}\right)$ dan material keras atau agregat $\left(\Omega_{2}\right)$. Interface antar kedua material ini diatur utuh atau tidak mengalami kerusakan pada saat kondisi awal (Alfat \& Kimura, 2019). Secara keseluruhan penelitian ini dibagi atas 3 bagian desain yaitu (1) Retakan berasal dari bitumen aspal ke agregat, (2) Retakan berasal dari agregat ke bitumen aspal dan (3) Retakan pada material heterogen. Untuk lebih jelas dapat dilihat pada Gambar 1. Pada dua desain pertama, Desain (1) (2), ini dianggap sebagai desain sederhana dan menjadi desain uji sebelum dilakukan simulasi 
dengan menggunakan Desain 3. Pada desain 3, struktur bitumen aspal dianggap sebagai seperti partikel (Salemi \& Wang, 2018). Secara keseluruh, sifat fisik bahan yang digunakan untuk semua desain sama, seperti yang sudah dijelaskan pada bagian 2.2. Asumsi Penelitian.

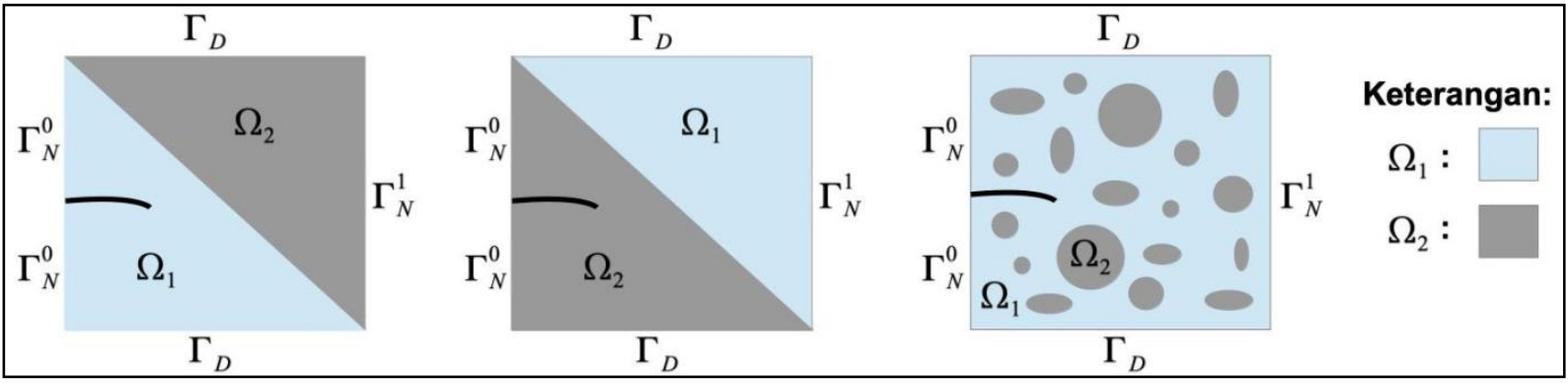

Gambar 1. Desain bahan heterogen dengan beberapa kondisi retakan; (kiri) dari bitumen aspal $\left(\Omega_{1}\right)$ ke agregat $\left(\Omega_{2}\right)$, (tengah) dari agregat $\left(\Omega_{2}\right)$ ke bitumen aspal $\left(\Omega_{1}\right)$, dan (kanan) material heterogen.

Sementara itu, adapun desain algoritma perhitungan pertumbuhan retakan untuk ketiga bahan heterogen yakni seperti pada Gambar 2 berikut:

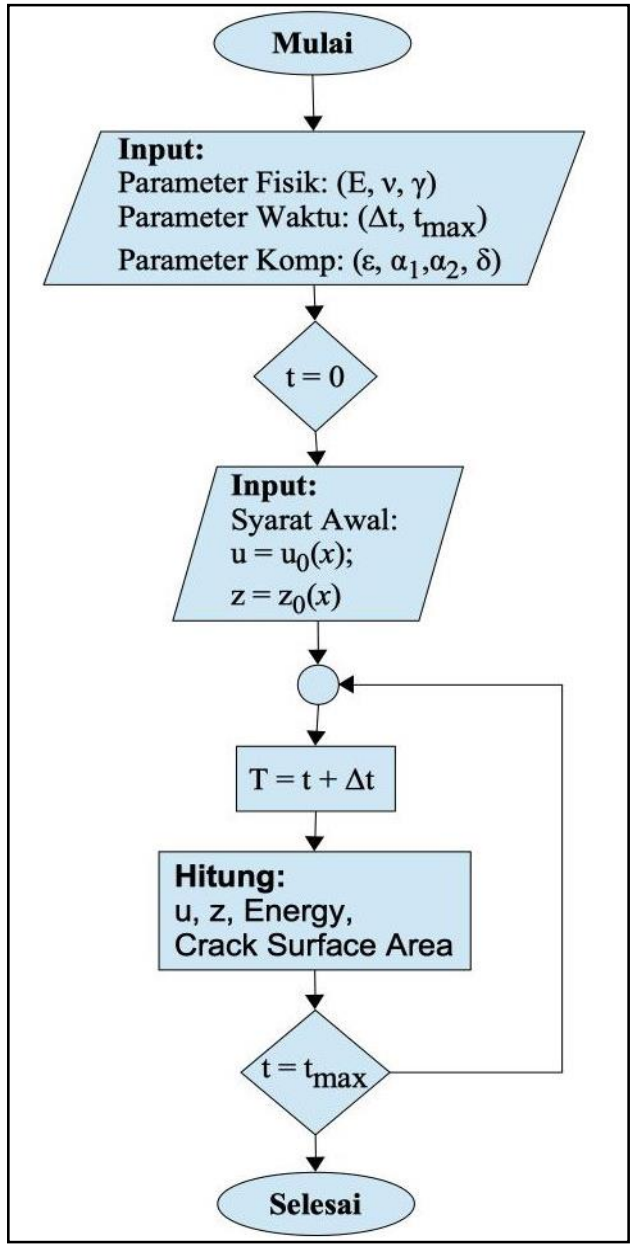

Gambar 2. Desain algoritma pertumbuhan retakan

\subsection{Metode Elemen Hingga}

Metode yang digunakan dalam penelitian ini adalah metode elemen hingga, maka perlu ditentukan semi-dikritisasi dalam waktu dan bentuk lemah (weak form) dari (3) dan (4). Karena persamaan pertumbuhan retakan merupakan persamaan yang saling berkaitan sehingga dalam menyelesaikan harus dilakukan secara serentak.

1. Semi-diskritisasi dalam Waktu

Untuk menyelesaikan masalah pada persamaan (3) dan (4), perlu dilakukan semidiskritisasi dalam waktu, atur $\Delta t>0, k$ adalah konstanta pertambahan waktu, dan $t_{k}:=$ $k \Delta t(k=1,2,3, \ldots)$. Adapun pendekatan semidiskritsasi dalam waktu sebagai berikut:

$$
\left\{\begin{array}{l}
u^{k}(x) \approx u(x, k \Delta t) \\
z^{k}(x) \approx z(x, k \Delta t) \\
\frac{u^{k}-u^{k-1}}{\Delta t} \approx \frac{\partial u}{\partial t} \\
\frac{z^{k}-z^{k-1}}{\Delta t} \approx \frac{\partial z}{\partial t}
\end{array}\right.
$$

\section{Bentuk Lemah (Weak Form)}

Persamaan (3) dan (4) perlu ditentukan bentuk lemahnya dan diperlukan suatu fungsi uji. Untuk persamaan (3), Anggap bahwa fungsi ujinya adalah $w$ dimana $w \in V^{u}$, dengan $V^{u}:=$ $\left\{w \in H^{1}(\Omega) \mid w=0 \quad\right.$ pada $\left.\quad \Gamma_{D}\right\}, \quad$ sehingga persamaan (3) dapat diselesaikan,

$$
\begin{aligned}
& 0=\int_{\Omega}\left(\mu \operatorname{div}\left((1-z)^{2} \nabla u\right) w\right) d A \\
& 0=\mu \int_{\Omega}(1-z)^{2} \operatorname{div}(\nabla u) w d A
\end{aligned}
$$




$$
\begin{aligned}
& 0=\mu \int(1-z)^{2} \nabla^{2} u w d A \\
& 0=\left[-\mu \int_{\Omega}(1-z)^{2} \nabla u \cdot \nabla w d A+\cdots\right. \\
&\left.\int_{\Gamma_{N}}(1-z)^{2} \frac{\partial u}{\partial n} w d s\right]
\end{aligned}
$$

Selanjutnya, mengacu ke syarat batas, persamaan (7), dan mensubsitutisi persamaan (8), persamaan (9) dapat dibentuk kembali menjadi:

$$
0=\mu\left[-\int_{\Omega}\left(1-z^{1-k}\right)^{2} \nabla u^{k} \cdot \nabla w d A\right]
$$

Sedangkan, untuk persamaan (4), anggap fungsi ujinya adalah $v$ dimana variabel $v \in V^{z}$, dengan $V^{z}:=\left\{v \in H^{1}(\Omega) \mid z=0\right.$ pada $\left.\Gamma_{D}\right\}$, sehingga persamaan (4) dapat diselesaikan

$$
\begin{array}{r}
\int_{\Omega}\left(\alpha_{2} \frac{\partial z}{\partial t}\right) v d A=\int_{\Omega} \varepsilon \operatorname{div}(\gamma \nabla z) v d A-\cdots \\
\int_{\Omega} \frac{\gamma}{\varepsilon} z v d A+\int_{\Omega} \mu|\nabla u|^{2}(1-z) v d A
\end{array}
$$

atau,

$$
\begin{aligned}
& \int_{\Omega}\left(\alpha_{2} \frac{\partial z}{\partial t}\right) v d A+\int_{\Omega} \varepsilon \gamma(\nabla z \bullet \nabla v) d A+\cdots \\
& \int_{\Omega} \frac{\gamma}{\varepsilon} z v d A-\int_{\Omega} \mu|\nabla u|^{2}(1-z) v d A=0
\end{aligned}
$$

Sama halnya dengan persamaan (10), menggunakan syarat batas dan mensubstitusi persamaan (7) ke persamaan (10), persamaan (11) dapat dibentuk menjadi:

$$
\begin{gathered}
\int_{\Omega}\left(\alpha_{2} \frac{z^{k}-z^{1-k}}{\Delta t}\right) v d A+\int_{\Omega} \varepsilon \gamma\left(\nabla z^{k} \cdot \nabla v\right) d A+\cdots \\
\int_{\Omega} \frac{\gamma}{\varepsilon} z^{k} v d A-\int_{\Omega} \mu\left|\nabla u^{k}\right|^{2}\left(1-z^{k}\right) v d A
\end{gathered}
$$

Persamaan (10) dan (12) merupakan bentuk lemah dari persamaan retakan yang dikembangkan oleh Takaishi-Kimura. Kedua persamaan di atas diselesaikan dengan menggunakan P2 Adaptive Metode Elemen Hingga dan Phase Field. Perhitungan menggunakan Software FreeFEM++ (Hecht, 2012), yang merupakan adaptasi dari bahasa $\mathrm{C}++$. Kemudian, data hasil simulasi numerik diplot menggunakan bantuan GNUplot.

\section{HASIL DAN PEMBAHASAN}

Bagian ini merupakan bagian yang sangat penting karena menampilkan hasil simulasi numerik, perilaku retakan dan pengaruh yang terjadi pada bitumen aspal. Serta tingkat energi elastisitas dan energi permukaan pada bitumen aspal. Adapun hasil simulasi numerik sebagai berikut.

\subsection{Perilaku Pertumbuhan Retakan pada Bitumen Aspal}

3.1.1 Hasil Simulasi Numerik pada Material Bitumen Aspal - Agregat

Hasil simulasi numerik dengan posisi retakan awal dari material lunak (bitumen aspal) ke material keras (agregat) menghasilkan pola atau perilaku pertumbuhan retakan, seperti pada Gambar 3.

Secara umum, dari hasil simulasi terlihat pada $\mathrm{t} \approx 0.75$, kerusakan dan pertumbuhan retakan masih terjadi pada ujung retakan awal. Saat $\mathrm{t} \approx 7.5$, pada material belum terjadi kerusakan yang signifikan. Saat waktu $\mathrm{t} \approx 10$, kerusakan dan pertumbuhan retakan terjadi dengan cepat. Pada $t=15$, retakan sudah sempurna dan membagi dua material. Ilustrasi ini dapat diamati melalui kurva Desain 1 pada Gambar 4, kemiringan kurva landai antara $0 \leq \mathrm{t}<$ 8 , ini menunjukan belum terjadi kerusakan yang signifikan. Namun saat $\mathrm{t} \leq 10$, kemiringan kurva menanjak naik dan menjadi datar (flat) saat $\mathrm{t} \approx$ 14.5 , ini artinya bahwa pertumbuhan retakan sangat cepat saat $\mathrm{t} \leq 10$ dan material rusak total (terbagi dua) saat $t \approx 14$. Secara keseluruhan, arah kerusakan material tersebut mengikuti batas antara kedua material lunak (bitumen aspal) dan keras (agregat).

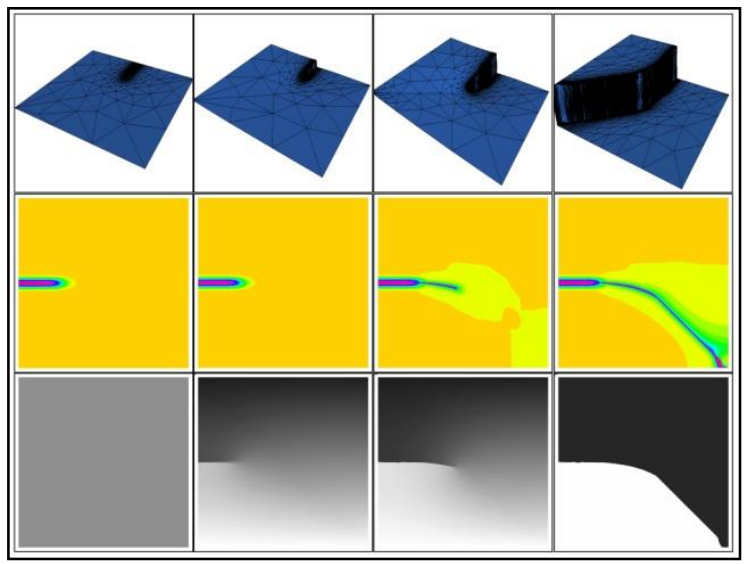

Gambar 3. Hasil simulasi pertumbuhan retakan dari bitumen aspal ke agregat pada $\mathrm{t}=0,6,12$, 15; (atas) 3D, (tengah) Phase Field, dan (bawah) Displacement.

Hasil simulasi menunjukkan penjalaran retakan dari bitumen aspal ke agregat pada 
rentang waktu $t=0$ sampai $t \approx 10$, arah retakan bergerak lurus, ini dikarenakan daerah retakan berada pada material yang lunak, sehingga tidak mendapatkan hambatan pada saat menjalar. Ketika saat retakan mencapai permukaan material yang keras (agregat) pada rentang waktu $\mathrm{t} \approx 10$ hingga $\mathrm{t} \approx 15$, arah retakan berbelok dan bergerak mengikuti batas tepi antara bitumen aspal dan agregat, ini disebabkan retakan tersebut tidak mampu melewati permukaan material yang keras, sehingga retakan mencari daerah yang lunak agar mudah dilewatinya sampai material terbelah dua.

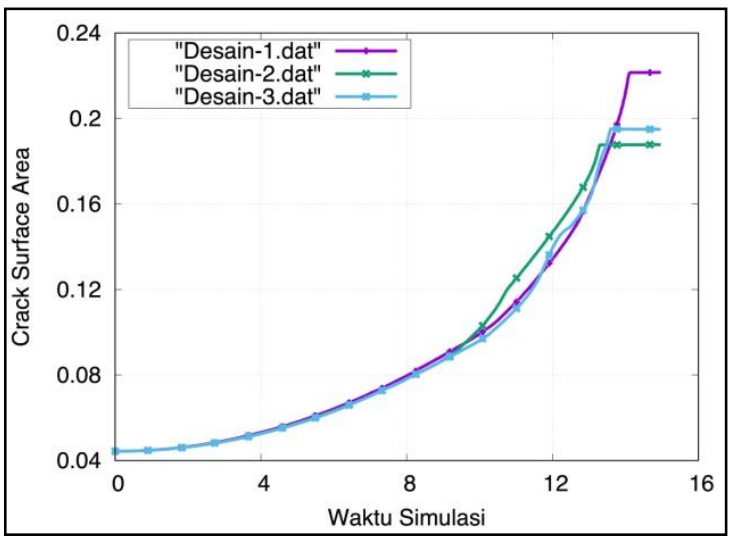

Gambar 4. Perbandingan besar area retakan (crack surface area) untuk 3 karakteristik domain yang berbeda.

\subsubsection{Hasil Simulasi Numerik pada Material Agregat - Bitumen Aspal \\ Hasil simulasi numerik kedua dengan} posisi retakan awal dari material keras (agregat) ke material lunak (bitumen aspal) menghasilkan prilaku pertumbuhan retakan seperti pada Gambar 5.

Dari hasil simulasi, kurva Desain 2 Gambar 4, pada selang waktu $0 \leq t<8$, kerusakan dan pertumbuhan retakan masih terjadi di sekitar ujung retakan awal. Namun, pada $t \approx 10$, kerusakan dan pertumbuhan retakan terjadi dengan sangat cepat. Pada $t \approx 13.3$, retakan telah membelah material dengan sempurna. Jika dibandingkan dengan Desain 1 dan 3, besar area retakan pada material Desain 2 cenderung kecil. Akan tetapi laju kerusakannya sangat cepat, ini ditandai dengan kemiringan kurva yang sedikit curam saat $t \leq 10$. Pada kasus ini Secara keseluruhan, arah kerusakan material tersebut cenderung mengikuti arah retakan awalnya, ini seperti ditunjukan pada Gambar 5.

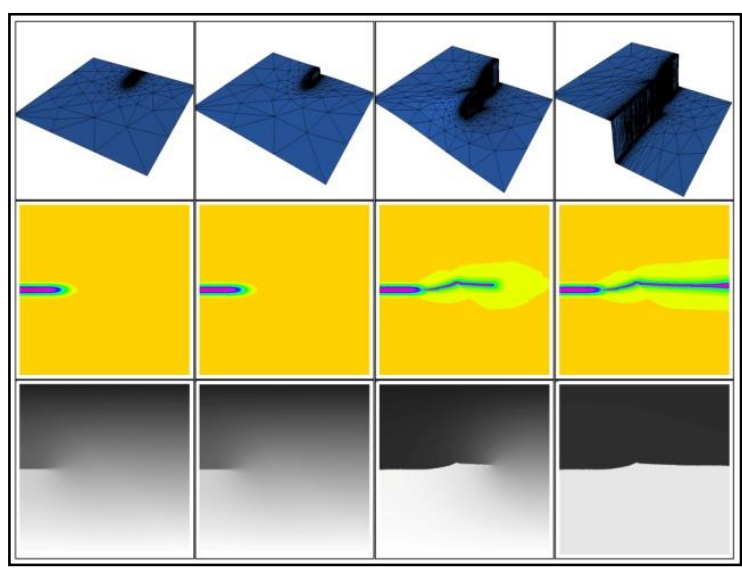

Gambar 5. Hasil simulasi pertumbuhan retakan dari agregat ke bitumen aspal pada $t=0,6,12$, 15; (atas) 3D, (tengah) Phase Field, dan (bawah) Displacement.

Hasil simulasi menunjukkan penjalaran retakan dari agregat ke bitumen aspal pada rentang waktu $\mathrm{t}=0$ sampai $\mathrm{t} \approx 10$, arah penjalaran retakannya bergerak lurus, dikarenakan retakan berada pada daerah material yang kuat (agregat). Dalam rentang waktu $t \approx 10$ hingga $t=15$, arah retakan tidak banyak mengalami perubahan pada penjalaran retakannya sampai material terbelah menjadi dua. Meskipun demikian, retakan mengalami sedikit pembelokan, tetapi arah retakan masih mengikuti arah retakan awalnya. Hal ini disebabkan, karena saat retakan menyentuh permukaan material yang lunak, retakan tidak mendapatkan hambatan yang besar, sehingga retakan dengan mudah melewati material tersebut.

\subsubsection{Hasil Simulasi Numerik pada Material} Heterogen

Hasil simulasi numerik ketiga pada material heterogen menghasilkan prilaku pertumbuhan retakan seperti pada Gambar 6 .

Hasil simulasi tersebut menunjukan pada waktu $\mathrm{t} \approx 0.75$ kerusakan dan pertumbuhan retakan masih terjadi pada ujung retakan. Waktu $\mathrm{t} \approx 7.5$, material belum mengalami kerusakan yang signifikan. Pada $t \approx 10$ kerusakan dan pertumbuhan retakan terjadi dengan cukup cepat. Pada $t \approx 13.5$ retakan sudah sempurna dan material terbelah. Hal ini terkonfirmasi melalui Kurva Desain 3 Gambar 4. Dari gambar tersebut juga, perilaku tersebut serupa dengan Desain 1, namun besar area kerusakannya tidak sebesar Desain 1. Secara keseluruhan, arah kerusakan material tersebut mengikuti batas antara kedua 
material lunak dan keras dan arah retakan awalnya.

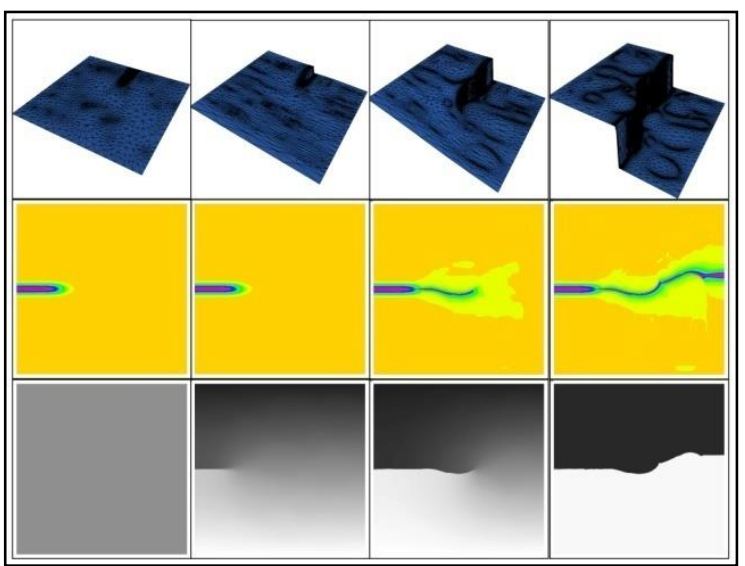

Gambar 6. Hasil simulasi pertumbuhan retakan pada bahan heterogen saat $\mathrm{t}=0,6,12,15$; (atas) 3D, (tengah) Phase Field, dan (bawah) Displacement.

Pada kasus ini, terdapat 2 jenis atau pola retakan yakni pola retakan lurus dan melengkung atau berbelok. Kedua pola ini disebabkan karena struktur material tersebut terdiri atas material kuat dan lemah, ini seperti yang ditunjukan pada Desain 3 Gambar 1. Saat retakan melewati daerah yang sama seperti yang dilewati sebelumnya maka terjadi retakan lurus. Akan tetapi, saat retakan membentur atau melewati material dengan karakteristik yang berbeda dengan material sebelumnya, maka akan terjadi pembelokan retakan. Pembelokan retakan menyusuri bagian tepi dari agregat. Ini karena retakan tidak mampu melewati atau

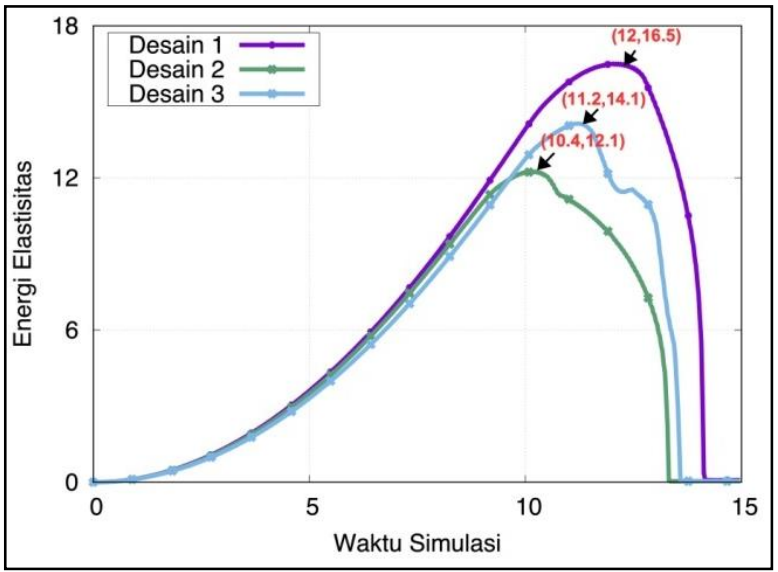

(a) membelah agregat, sehingga retakan mencari daerah lain yang mudah untuk dilewatinya sampai material terbelah menjadi dua.

Hasil simulasi menunjukkan bahwa waktu untuk terjadinya retakan dan proses perambatan retakan berbeda pada setiap domain. Ini dapat dilihat pada simulasi numerik pertama dengan posisi retakan awal dari material lunak (bitumen aspal) ke material keras (agregat) di $\mathrm{t} \approx 12$, retakan belum mencapai titik pusat material. Sedangkan pada simulasi lain, saat $\mathrm{t} \approx 12$ sudah terjadi retakan dengan panjang retakan yang berbeda-beda. Ini juga terkonfirmasi melalui Gambar 4, itu menunjukan bahwa waktu retakan sempurna (material terbagi dua) cenderung lama pada Desain 1.

\subsection{Energi Elastisitas dan Energi Permukaan}

Sesi sebelumya hanya menjelaskan pola atau perilaku retakan pada material dan tidak mengungkapkan secara spesifik tentang kapan dimulainya kerusakan dan retakan awal pada sebuah material. Pada sesi ini, kami akan menjelaskan waktu kerusakan dan retakan awal sebuah material dengan menampilkan hasil profil energi elastisitas dan permukaan untuk masing-masing desain material. Kedua energi tersebut diperoleh dengan menggunakan persamaan:

$$
\begin{aligned}
& \mathrm{E}_{\text {elastic }}=\frac{1}{2} \int_{\Omega}(1-z)^{2}|\nabla u|^{2} d x-\int_{\Omega} f u d x \\
& \mathrm{E}_{\text {surface }}=\frac{1}{2} \int_{\Omega} \gamma\left(\varepsilon|\nabla z|^{2}+\frac{1}{\varepsilon} z^{2}\right) d x
\end{aligned}
$$

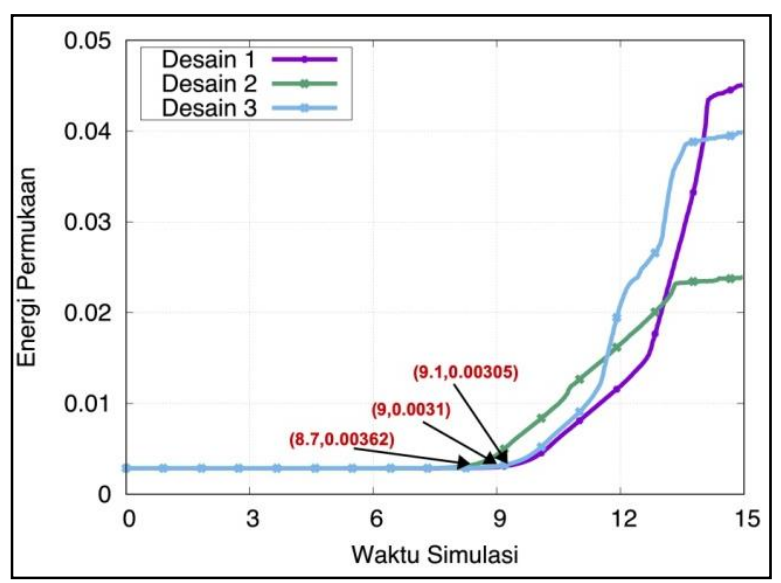

(b)

Gambar 7. Grafik (a) energi elastisitas dan (b) energi permukaan pada tiga desain kasus berbeda. 
Perubahan energi elastisitas dan permukaan dapat menjelaskan secara spesifik mengenai kemampuan material bertahan terhadap suatu pembebanan eksternal (the external load), waktu terjadinya pertumbuhan retakan baru dan kerusakan total (material terbagi dua). Setiap material dengan pembebanan yang berbeda memiliki profil perubahan energi elastisitas dan permukaan yang berbeda pula (Alfat \& Asfar, 2017). Kami juga melihat bahwa profil energi elastisitas dan permukaan akan berbeda jika karakteristik material berbeda.

Dari hasil perhitungan energi elastisitas, Gambar 7(a), menunjukan adanya perbedaan nilai pada energi tersebut untuk masing-masing desain. Disamping itu, waktu untuk mencapai nilai maksimum berbeda-beda pula. Dari ketiga desain material tersebut, energi elastisitas terbesar dan waktu terlama untuk mencapai nilai maximum terdapat pada Desain 1 dan yang terendah pada Desain 2. Ini mengindikasikan bahwa Desain 1 tidak cepat retak, adapun Desain 2 memiliki kecenderungan mudah retak. Pada Desain 1 , retakan baru terjadi pada $\mathrm{t}=12$ dengan energi elastisitas maksimum berada pada 16.5. Adapun kedua desain lain, Desain 2 dan 3, retakan baru terjadi pada $\mathrm{t}=10.4$, dan $\mathrm{t}=11.2$ dengan energi elastisitas maksimum masingmasing sebesar 12.1 dan 14.1.

Sekarang mari melihat mengenai energi permukaan. Energi ini dapat mengindikasikan dan mengetahui waktu kerusakan awal suatu material. Pada dasarnya dengan melihat energi elastisitas, suatu material dapat diklasifikasikan tingkat kekuatannya dengan mudah, artinya kita dapat menduga material dengan struktur seperti apa yang mudah rusak dan tentunya mudah retak. Namun energi elastisitas tidak bisa mengetahui saat pertama kali material rusak, energi tersebut hanya bisa melihat retakan baru, dengan begitu kehadiran profil energi permukaan dibutuhkan pada kondisi ini. Sebagai catatan, pendekatan phase field membagi tingkat perubahan bentuk material kedalam tiga fase yakni tidak rusak, rusak, dan retak.

Hasil perhitungan numerik, Gambar 7(b), diperoleh bahwa material Desain 2 cepat rusak sedangkan Desain 1 tidak mudah rusak. Ini ditandai dengan adanya perubahan nilai energi permukaan yang signifikan untuk masingmasing desain pada waktu tertentu. Perubahan energi permukaan yang tercepat adalah Desain 2 pada $\mathrm{t}=8.7$ dengan perubahan energi permukaan sebesar 0.00362, sedangkan Desain 1 dan 3 pada $t=9.1$ dan $t=9.0$ dengan perubahan energinya masing-masing adalah 0.00305 dan 0.0031 . Hal menarik lainnya yang dapat diamati melalui perubahan energi permukaan adalah tingkat kerusakan suatu material. Dari Gambar 7(b) terlihat bahwa kerusakan dan retakan terbesar dialami oleh Desain 1. Adapun Desain 2 memiliki tingkat kerusakan dan retakan yang sangat kecil. Kondisi ini akan terkonfirmasi jika membandingkan dengan hasil retakan yang ditampilkan pada Gambar 3, 5, dan 6, tentu juga jika disandingkan dengan Gambar 4 mengenai grafik besar area retakan untuk setiap desain.

Catatan penting lainnya yang diperoleh dari grafik energi elastisitas dan permukaan adalah waktu yang dibutuhkan untuk terjadinya retakan sempurna pada suatu material dihitung saat terjadinya retakan dan kerusakan baru di ujung retakan awal begitu sangat cepat. Hal ini dapat dilihat dengan penurunan kurva pada Gambar 7(a) yang sangat cepat. Fenomena ini juga akan terkonfirmasi pada Gambar 3, 5, dan 6, dimana pertumbuhan retakaan belum terjadi saat $t=0$ hingga $t=6$, akan tetapi retakan tidak membutuhkan waktu yang lama saat membagi dua material, itu terjadi antara selang waktu $6<$ $\mathrm{t}<15$.

\section{KESIMPULAN}

Berdasarkan hasil dan pembahasan dapat di simpulkan bahwa material dengan desain struktur yang berbeda memiliki perilaku retakan yang berbeda pula. Disamping itu, waktu terjadinya retak sempurna (terbagi dua) untuk setiap struktur material berbeda-beda. Material dengan struktur Desain 1, waktu yang dibutuhkan untuk retak sempurna pada $t \approx 14,5$. Material dengan struktur Desain 2 dan Desain 3, waktu yang dibutuhkan sehingga terjadi retak sempurna masing-masing adalah $\mathrm{t} \approx 13,3$ dan $\mathrm{t} \approx$ 13,6 . Semakin lambat laju pertumbuhan retakan pada material maka semakin besar energi elastisitas, sebaliknya semakin cepat laju pertumbuhan retakan pada material, maka semakin kecil energi elastisitas. Perubahan energi permukaan yang signifikan pada sebuah material mengindikasikan bahwa material tersebut telah dan sedang mengalami kerusakan. Sebagai tambahan, waktu retakan saat pertama kali muncul retakan baru di ujung retakan awal hingga rusak sempurna (material terbagi dua bagian) sangat cepat. 


\section{DAFTAR PUSTAKA}

Alfat, S., \& Asfar, S. (2017). Investigasi Numerik Pengaruh Sudut Geser Terhadap Energi Elastisitas dan Permukaan Menggunakan Adaptive Finite Element MEthod. Seminar Nasional Riset Kuantitatif Terapan 2017, April, $\quad$ 90-99. http://ojs.uho.ac.id/index.php/snrkt2017/ article/view/3257/2500

Alfat, S., \& Kimura, M. (2019). A Micromechanical simulation of Crack Propagation in Heterogeneous Composite Solid. JSIAM Annual Meeting 2019, 2019(3), 3-4.

Alfat, S., Kimura, M., Firihu, M. Z., \& Rahmat. (2018). Numerical investigation of shape domain effect to its elasticity and surface energy using adaptive finite element method. AIP Conference Proceedings. https://doi.org/10.1063/1.5038293

Antes, H. (2016). A Short Course on Boundary Element Methods Heinz Antes To cite this version: HAL Id: cel-01352830 A Short Course on Boundary Element Methods. https://cel.archives-ouvertes.fr/cel01352830

Causon, D. M., \& Mingham, C. G. (2010). Introductory Finite Difference Methods for PDEs.

http://www.cs.man.ac.uk/ fumie/tmp/int roductory-finite-difference-methods-forpdes.pdf

Font, R., \& Periago, F. (2013). The Finite Element Method with FreeFem ++ for beginners. The Electronic Journal of Mathematics Ans Technology.

Hecht, F. (2012). New development in freefem+. Journal of Numerical Mathematics. https://doi.org/10.1515/jnum-2012-0013

Kimura, M., Komura, H., Mimura, M., Miyoshi, H., Takaishi, T., \& Ueyama, D. (2005). Adaptive mesh finite element method for pattern dynamics in reaction-diffusion systems. Proceedings of the Czech-Japanese Seminar in Applied Mathematics.

Luding, S. (2008). Introduction to discrete element methods: Basic of contact force models and how to perform the micromacro transition to continuum theory. European Journal of Environmental and Civil Engineering. https://doi.org/10.1080/19648189.2008.9 693050

Mashuri, \& Patunrangi, J. (2011). Perubahan
Karakteristik Mekanis Aspal yang Ditambahkan Sulfur sebagai Bahan Tambah. Jurnal Mektek, 13(2). https://media.neliti.com/media/publicatio ns/154646-ID-perubahan-karakteristikmekanis-aspal-ya.pdf

Pfingsten, T., \& Glien, K. (2006). Statistical analysis of slow crack growth experiments. Journal of the European Ceramic Society. https://doi.org/10.1016/j.jeurceramsoc.20 05.08.004

Ritonga, W., \& Irfandi, I. (2016). Pengaruh Karet Alam Siklik (Cyclic Natural Rubber) Terhadap Rongga Aspal Modifikasi. Jurnal Pendidikan Fisika Indonesia, 12(2), 169176. https://doi.org/10.15294/jpfi.v12i2.4389

Salemi, M., \& Wang, H. (2018). Image-aided random aggregate packing for computational modeling of asphalt concrete microstructure. Construction and Building Materials. https://doi.org/10.1016/j.conbuildmat.20 18.05.139

Takaishi, T., \& Kimura, M. (2010). Phase Field model of mode III-type crack evolution and its energy estimation. 21-25. http://www.kurims.kyotou.ac.jp/ kyodo/kokyuroku/contents/pdf/ 1719-04.pdf

Takeshi, T., \& Kimura, M. (2009). Phase field model for mode III crack growth in two dimensional elasticity. Kybernetika.

Tanaka, H.; Aoki, Y.; Yamamoto, S. (1997). Evaluating Reliability: The Mechanism of Solder Cracking. In Technology. https://espec.com/images/uploads/files/T echReports/tech_rep_03.pdf

Tilbrook, M. T., Moon, R. J., \& Hoffman, M. (2005). Curved crack propagation in homogeneous and graded materials. Fatigue and Fracture of Engineering Materials and Structures. https://doi.org/10.1111/j.14602695.2005.00927.x 